\title{
11. Self-regulation as a tool for ensuring media accountability: The Kenyan experience
}

\section{ABSTIRACI}

This article examines self-regulation as a mechanism of media accountability in Kenya. It is based on a study that explored the role of the Media Council of Kenya in self-regulation and the challenges it faces in performing this role. Data came from indepth interviews, document reviews and direct observation. Through effective institutional mechanisms, self-regulation is the preferred system of promoting ethical standards in the media in Kenya. However, the system is currently beset by a myriad challenges, among them lack of commitment by the media industry and a crisis of confidence in its ability to rein in errant media.

Keywords: Kenya, media accountability, press council, media self-regulation

\section{JARED OBUYA \\ Moi University, Kenya}

TT IS important the public not only holds politicians and other state officials accountable, but also that those individuals and institutions such as journalists and the media, who monitor the state, should themselves be held accountable for their actions (Tettey, 2002). The failure of monitoring institutions to perform according to democratic norms and in the true interest of society erodes their credibility and, therefore, damages their ability to serve as legitimate watchdogs over state activity. Thus, the mass media, while serving as autonomous agents of accountability, are themselves not immune from operating within the parameters of its principles (Ibid).

It is therefore important that the media be held answerable to the various publics that they serve and be subject to necessary sanctions if they stray in discharging their responsibilities because there is no way the profession can obtain public support unless it listens to readers/listeners/viewers-unless it is accountable to them (Bertrand, 2005). 
However, the question of media accountability remains in a conceptual muddle (Dennis \& Gillmor, 1989), being one of the unresolved issues of contemporary journalism (Desbarats, 1990). One difficulty in resolving the issue is the fact that scholars and journalists lack an adequate understanding of accountability (Christians, 1989).

This article rests on the assumption that the conceptual muddle cannot be clarified without a careful exploration of the mechanisms of media accountability (Pritchard, 1991).

McQuail (2005) argues that the process of compelling the media to conform to the standards of society and holding them answerable to those standards is what media accountability is about. He defines media accountability as all the voluntary or involuntary processes by which the media answer directly or indirectly to their society for the quality of and/or consequences of publication, the core reference of which is a process of public scrutiny, whereby the public activities of the media are confronted with legitimate expectations of the society.

The essence of accountability lies in naming, shaming and claiming. Essentially this means identifying a problem, naming the offending media, and claiming apology or compensation (Pritchard, 2000).

McQuail (2009) names two stages of accountability: internal and external accountability. The former involves control within the media such that specific acts of publication such as news items and TV programmes can be made the responsibility of media organisations and their owners. However, internal control cannot be relied upon to satisfy the wider social need for accountability since internal mechanisms can either be too strict, thus acting as a form of self-censorship, or too much directed at serving the interests of the media organisation.

External accountability, on the other hand, is the relationship between the media and those affected or interested by its publication. McQuail (2009) identifies accountability relations here to involve the media and audiences, social institutions, clients such as advertisers, public opinion, owners, sources, regulators, referents and pressure and interest groups. Self-regulation, one of the most important tools of media accountability falls under external accountability (Pritchard 2000).

Jean-Claude Bertrand (2005) gives two scenarios from which self-regulation results; a situation where media owners initiate auto-discipline for fear 
that the government will legislate restrictions to their freedom of enterprise; or sometimes journalists initiate rules to ensure good service and to protect their profession. According to Pritchard (2000), the institution which normally gathers the media institutions, journalists and the public together in order to act as the instrument for the self-regulation of the media are known as Press Councils.

To promote responsible media behaviour, the Kenyan Parliament in 2007 passed the Media Act 2007, which established the Media Council of Kenya (a press council) to oversee ethical journalism and mediate in disputes between the media, the public and the government through self-regulation (Oriare, 2008). Despite the existence of a council to regulate standards, the performance of the media industry has been the subject of intense debate in Kenya, especially after the post-election violence that followed the disputed presidential elections in 2007 (Media Institute, 2010).

The debate surrounding self-regulation of the media is whether the existence of the Media Council of Kenya and the code of ethics and practice of journalism have in any way improved the standards of the profession in the country (Ibid). This article highlights the role of self-regulation in Kenya and the challenges encountered in using self-regulation as a tool for media accountability.

\section{The media in Kenya}

The Kenyan media is regarded as one of the most respected, thriving, sophisticated and innovative in Africa (Abdi \& Deane, 2008). It has become increasingly assertive and self-confident, playing a substantial role in mediating relationships between citizens and state, in shaping the democratic dispensation in the country, and has transformed how some of the most marginalised in society access information on issues that shape their lives. Kenyan citizens have become increasingly reliant on the media for information, investing it with greater credibility than almost any other source of information (Ibid).

Oriare and Mshindi (2008) point out that the Kenyan media has been a fierce defender of good governance and democracy and has provided a platform for opposition and civil society organisations to champion democracy. The public has therefore maintained a huge trust in the media's ability to check the other arms of government to the extent of replacing the official opposition 
in Parliament in checking the excesses by the government (Friedrich Ebert Stiftung, 2010).

Interrogative and analytical reporting by the media on national issues has been on the rise and incisive coverage of key national events like the referendum, military recruitment, appointment of government officers and corruption in state ministries has taken the centre stage of media reportage (Ibid).

Although the media is seen as the most trusted public institution, it has also been blamed for the country's biggest failing ever. In December 2007, a disputed presidential election caused unprecedented violence in the country's history and the media was accused of political bias; fanning the embers of ethnic hatred and marginalising voices of reason in an ethnically polarised political environment (Abdi \& Deane, 2008).

\section{Media accountability in Kenya}

Kenya has constitutional guarantees for freedom of expression, freedom of the media and freedom of information (Constitution of Kenya, 2010). Before the Constitution was enacted in 2010, the overall regulatory environment for the media was a complex one with many statutes affecting the media, including the Official Secrets Act, Public Order Act, Defamation Act and Preservation of Public Security Act (Oriare, 2008).

However, the conduct and discipline of journalists as professionals is governed by the Media Act 2007, which established the Media Council of Kenya for the self-regulation of the media (Oriare, 2008). The coming to power of the National Rainbow Coalition in 2003 had seen an unprecedented growth in the broadcast sector, especially FM radio stations, which were bold, unbridled and ridiculing politicians. Several MPs, including Information Minister Raphael Tuju accused the FM stations of airing pornography, political propaganda and being defamatory (BBC, 2003).

Some of the stations, broadcasting in tribal languages, were also seen to have become dangerously biased, reflecting the ethnic-centred wrangling that was then taking place within the ruling coalition (Ibid). To protect the profession from the onslaught by politicians that was getting out of hand, media owners, representatives of journalists and media training institutions successfully lobbied the government to initiate the process that led to the establishment of the council (Oriare, 2008).

In 2007, the Media Council of Kenya - controlled by the media-was 
established through an Act of Parliament as the main regulatory body for media in Kenya, with the mandate to mediate in disputes between the media, the public and the government and administrate the conduct of journalists as professionals by ensuring adherence to the code of conduct for the practice of journalism.

The Media Council of Kenya is composed of three groups: media owners, professional journalists and members of the public. The council was duly constituted according to the Media Act 2007. It comprises three people nominated by Media Owners Association (MOA), two people nominated by the Kenya Union of Journalists (KUJ), two people nominated by schools of journalism of recognised universities with each representing public and private universities, and one person each representing the Kenya Correspondents Association, Public Relations Society of Kenya (PRSK), Editors Guild, the Kenya Institute of Mass Communications (KIMC), Ministry of Information and the Law Society of Kenya.

In order to execute its mandate, the council members are divided into three committees: The Accreditation and Training Committee, which oversees the registration and accreditation of journalists and the training functions of the council; The Ethics and Public Information Committee, which oversees the adherence to the Code of Conduct for the Practice of Journalism by media practitioners and the publicity of the council; and the Finance and Administration Committee which is charged with the financial and administrative operations of the council (Media Council of Kenya, 2009).

Complaints are handled by the Complaints Commission which comprises five commissioners. The Complaints Commission is constituted as an independent arm of the Media Council. The secretariat is the executive arm of the council and is headed by the executive director who is also the secretary to the council.

The functions of the Media Council of Kenya are meant to promote and protect the freedom and independence of the media (Media Council of Kenya, 2009). They include:

- Mediate or arbitrate in disputes between the government and the media, between the public and the media and intra-media.

- Promote and protect the freedom and independence of the media.

- Promote high professional standards among journalists.

- Enhance professional collaboration among media practitioners. 
- Promote ethical standards among journalists and in the media.

- Ensure the protection of the rights and privileges of journalists in the performance of their duties.

- Advise the government or the relevant authority on matters pertaining to professional education and the training of journalists and other media practitioners.

- Make recommendations on the employment criteria for journalists.

- Uphold and maintain the ethics and discipline of journalists.

- Compile and maintain a register of journalists, media practitioners, media enterprises and such other related registers.

- Conduct an annual review of the performance and the general public opinion of the media, and publish the results (Media Council of Kenya, 2009).

\section{Methodology}

Qualitative data generation techniques such as indepth interviews, document reviews and direct observation were used to generate data for this article.

\section{Indepth interviews}

Indepth interviews lasting 40-60 minutes were held with 15 people who were considered to have sufficient knowledge about the media and the Media Council of Kenya in October 2009. Fourteen of the respondents were interviewed face to face in conformity with the recommendations of Babbie and Mouton (2001), who suggest that between 8-12 interviewees for this kind of research is adequate. One participant was interviewed by telephone as it was found difficult to meet her face to face because of her tight daily schedules.

The list of interviewees included four editors, three leaders of journalism bodies, one human rights lawyer, two academics, two current Media Council of Kenya members and one government official. Two staff members at the council's secretariat were also interviewed. These were purposively selected, taking into consideration expertise, experience and availability, among other factors.

The interviews took the form of ordinary conversations. An interview guide contained the main questions while the probes were determined as the conversations proceeded. Respondents were not only asked about facts but also their opinions on the subject of inquiry. 


\section{Document review}

Document review is another data generation technique that was employed by this study. Using documentary sources in research serves to supplement the material the researchers collect themselves; as a primary focus of research; and to corroborate the other evidence (Yin, 2009).

Some of the documents reviewed included the State of the Media report, minutes of meetings, files on the complaints received against the media, deliberations of the Complaints Commission, policy documents, media strategy and publicity documents, general documents such as mission and vision statements, financial and budgetary documents, and minutes of meetings. The documents were obtained from the Media Council of Kenya through the necessary permission.

\section{Direct observation}

In general terms, Mason (1996) enunciates three reasons why researchers turn to observational research. First, researchers choose observation as a technique of data gathering based on ontological beliefs. That is, a belief where one considers interactions and behaviours and the way people make sense of them as a key to social life. Second, researchers choose it when natural or real-life settings are expected to reveal social reality. This is to establish validity and adequacy. Third, observation is used when the researcher believes that observation generates information of enough complexity and richness on a case.

Direct observation was used to ascertain the location of the offices, the technology used in the workplace such as computers or video-conferencing facilities; the demeanour of the staff. An observation of a full council meeting to gauge the deliberations and see how complainants and defendants actually present their cases and how the cases are deliberated upon was planned. However, it emerged that the council had not held any sitting in the previous year and did not hold any during the course of the research.

\section{Findings}

The data is presented in narratives using quotations, summaries and paraphrases from the above-mentioned data sources. The main body of data subjected to analysis and interpretation is interview data, while observations and documents were used to cross-check for the validity of the information. Texts that are quoted are those that are deemed to be the most concise 
and useful ones. While the concepts covered may be overlapping, theme by theme presentations was used for analytic reasons.

\section{Structure of the council}

Many respondents felt that the council was dominated by media practitioners and there was no way the media would effectively audit themselves. It was widely felt that the industry needed to rethink the structure of the council. One respondent stated:

The structure of the council does not give it energy. They are not inspired to move because of vested interests. It is mainly composed of media.

Indeed, representation at the council is skewed in favour of the media as all but two (Law Society of Kenya and Public Relations Society of Kenya) representatives belong to the industry.

\section{Functions of the council}

Findings from the interviews left no doubt that media practitioners recognised and looked up to the council as the only body with the authority to ensure standards in the media industry in Kenya. However, all the respondents stated that the council's overall performance was far from satisfactory. One respondent, who is a member of the council, stated:

We've not done enough because of several obstacles. For this reason the ordinary people are disenfranchised in the process of media justice because the rich folk can resort to the courts as they have the means to do so.

Several respondents confirmed that the council had done an audit of the media in the country but this had not been made public as required by law. Documents reviewed at the council confirmed this. Article 4(1) of the Media Act 2007 states that among other functions the council shall:

Conduct an annual review of the performance and the general public opinion of the media, and publish the results thereof in at least two local newspapers. (Kenya Gazette Supplement, Acts, 2007)

The council had been publishing a quarterly newsletter, The Media Observer, which tackles media issues. Some respondents said the newsletter was 
not in the public domain and that the majority of journalists did not know that it existed.

However, the council, together with other media bodies, had successfully lobbied the government to change the composition of the media content regulatory authority to include media practitioners, and was instrumental in lobbying for the amendment of the Media Act 2007 to allow for government funding of the council.

Some respondents felt that the council's objectives, enumerated in the previous section, were too broad and needed to be changed to focus on its core mandate, which should be to adjudicate disputes and enforce standards through the administration of the code of conduct.

\section{The Complaints Commission}

The study found that the council had put in place a Complaints Commission as informed by the law. The work of the Complaints Commission is to adjudicate disputes between members of the public and the media, journalists and media and within the media.

Documents at the council indicated that there had been 24 valid complaints since 2007. However the council had yet to resolve a single case. One of the staff members at the council confirmed that since the commission gazetted its rules of procedure eight months earlier, it had yet to hold a single sitting. On this, one respondent, who is a government official commented:

There is no single case that the council has adjudicated. That's why people are resorting to the courts. I know for a fact that the vice-president has a case against a certain media house for this reason. The council has refused to use its power to punish errant media. It is moribund and will never be in a position to do anything. The council is like NEPAD ${ }^{1}$, a body for conferences, travelling and meetings.

The study also found that the process of complaining was 'cumbersome and disenfranchising to the ordinary people', according to one of the respondents, who is a member of the council. According to the Complaints Commission rules of procedure, complainants must fill a form - picked up in person from the council's offices - for the process to begin. No emails, calls or SMSs from the complainants are entertained.

Most of those interviewed also contended the penalties for errant behaviour 
were not punitive enough to deter rogue journalists or media houses and that the Complaints Commission also lacked the power to enforce its judgements. Section 29 (1) of the Media Act states:

Without prejudice to the generality of Section 27 (2), the Complaints Commission or any of its panels may, after hearing the parties to a complaint -

a. and being of the opinion that the complaint is devoid of merit or substance, dismiss such complaint;

b. order an offending party to publish an apology and a correction in such manner as the council may specify;

c. issue a public reprimand of the journalist or media enterprise involved. (Kenya Gazette Supplement, Acts, 2007)

Respondents felt that since there were no deterrent measures in terms of penalties, rogue media or journalists could defy the council at will and the council would do nothing about it. These sentiments were captured in the words of one of the respondents:

The law does not give the council teeth to carry out its mandate. The council can only issue warnings. This is not enough. We have no recourse to the courts in case a media house defies the council.

There were also suggestions from some respondents that the council members and complaint commissioners should have permanent tenure to expediently act on complaints.

\section{Other challenges facing the council}

\section{Funding}

All respondents agreed that the biggest challenge to the successful operation of the council was lack of adequate funding. The Media Act 2007 did not provide for government funding of the council; neither did it allow for funding from donors. The Act envisaged that the council's funding would come from subscriptions from publishers and accreditation of journalists.

This point, by one respondent, captures the general feeling of virtually all the other respondents:

The performance of the council is not good enough because of lack of funding to cement the relationship with the public and promote its activities. 
Another respondent, who is a government official, however, blamed the lack of funding on the media owners, who, he claimed, were deliberately fronting a weak Media Council.

It is the agenda of media owners. They want the council to be conservative. During its formation, Treasury had agreed to allocate money for the council but media owners refused. So Parliament also refused to allow the council to be funded by donors. The council is now only funded by a few media houses controlling it.

Due to the funding challenges ${ }^{2}$ even the secretariat of the council was not functioning effectively. There were no facilities such as vehicles or computers and the secretariat itself was housed in very obscure and limiting premises in one of the suburbs of Nairobi. The council did not have enough space to conduct meetings or house the media monitoring unit, which requires adequate space and equipment. The monitoring unit itself had not been set up due to lack of resources, both material and human.

The council had only seven employees despite its huge mandate and these included an expatriate seconded by a German development agency, one secretary and an office assistant. Respondents said there was need for the law to be changed to allow for both government and donor funding for the council.

\section{Publicity}

All respondents stated that there was very little knowledge of the existence of the council, its role, functions or activities. This had made its relationship with its publics, namely the government, journalists and members of the general public, difficult.

According to respondents, the vast majority of the public did not know that there were channels for redress through the Media Council in case they were aggrieved by the media. Respondents said there were many people aggrieved by the media, but who didn't know how to engage with the media or where to channel their grievances. There was general ignorance even within the industry. According to respondents, few practitioners understood the role of the council and even fewer had read the Media Act, which established the council. The respondents said media practitioners did not even understand the laws that created the council, why it was created or what it did on a daily basis.

One respondent, who is a media manager, commented on the awareness challenge thus: 
The council is not visible and there is a general lack of awareness. There is even general ignorance within the industry. Practitioners do not seem to understand the role of the council. Some journalists even think that it is a trade union. Some of my staff do not understand the different roles played by the council, the Editors Guild of Kenya, the Media Owners Association or even the Kenya Union of Journalists (KUJ) and have come asking me for things from the council that can only be done by a trade union. Also, the council is supposed to make public its annual report in newspapers but it has not done so.

Another respondent commented on the lack of engagement:

The public don't know that there are channels for redress. The number of people who want to complain about the media is legion, but they don't know how to engage. The council is not engaging with the public or with the media industry. The council is not making itself relevant. They have had too few forums. They should be engaging with the media and organising forums, meeting editors, speaking on TV, holding workshops. The marketing of the council has been too feeble.

\section{Confidence crisis}

Many respondents felt there was a crisis of confidence in the council as members of the public feel they were unlikely to get justice from the council. According to most of the respondents, people had no confidence in the council because they felt the council could not act on their grievances. The council had also not adjudicated a single case, which was seen to be a big blow to its reputation. The council was seen as being dominated by media practitioners, who would be reluctant to punish their own misdeeds. They pointed out that the chairman of the media council was also the chief executive officer of an influential media house.

One respondent argued:

There are confidence issues as the council has yet to resolve a single case. People have no confidence in the council because they know the council cannot act on their grievances. Some people think the council is not active because it does not want to punish its own. The chairman should not be from the media. The complaints commission should also not be appointed by the council. 
One of the respondents expressed hopelessness about the situation:

Kenyans don't see hope. They complain but nothing is being done. We must always have the remote in our hands in our sitting rooms as some of the programmes could embarrass you with your children. But we're unable to complain because nothing will come of it.

The fact that the council did not have the power to impose stiff penalties, respondents said, made people seek justice in the courts of law. One respondent decried the situation:

Libel awards are huge, because judges feel the media are too powerful and people are helpless against them. Therefore there has been a determination to crackdown on media.

Some respondents said the government was also mistrustful of the council because it thought the council was representing the interests of the media owners who fund its operations. One respondent said people viewed 'the council as a public relations tool for the media owners' and 'a peer club for senior editors, media managers and practitioners'. The respondent, who is a member of the council, said:

The mistrust between the government and the council is undermining its operations. The government feels that the council is there to protect the interest of media owners. He who pays the piper plays the tune. Some leaders have gone to seek redress against media houses in the courts instead of the council because they don't trust it.

Another respondent echoed the above sentiments:

The government is complaining that the council has been taken hostage by the media owners and therefore incapable of being balanced in case the interests of the media owners are in jeopardy.

\section{Lack of commitment to accountability}

Some respondents saw the media industry as not genuinely desiring accountability. They saw the media as merely engaging in buying time from state control. The respondents observed that successful councils were those where the industry was committed. The respondents argued that the Kenyan media 
industry only showed commitment to accountability when they were threatened with state regulation. The media was not willing to go after itself, they argued.

The respondents also thought there were powerful interests in the media who were not willing to be questioned and wanted the state of affairs to remain as they were. This was captured in the sentiments of one of the respondents, who is a consultant editor:

I don't think that the powerful interests in the media are completely interested in the idea of media accountability. Few are willing to be questioned, so they would rather the status quo, that is, a weak media council.

Another respondent argued along the same lines:

There appears to be a deliberate lack of commitment from the media to be accountable, yet observing ethics would be the best way for their self-preservation. The media industry does not seem to have any values.

\section{Competing legislation}

There were punitive media laws that were undermining the council's role of adjudication of disputes. Some respondents felt that the competing legislations were fostering hostility towards the Media Council, portraying it as ineffective. One respondent commented that it was 'attractive' for the public to seek redress in the courts, because of the 'existing punitive media laws'. The respondents suggested that all media laws should be harnessed together under one media act administrated by the council in order to overcome this obstacle.

\section{Divided loyalties}

Respondents noted that the council members and the complaints commissioners were professionals working elsewhere, so it took time and resources to assemble them. The council members were not permanent and had divided loyalties.

'They don't even have time to attend meetings,' a respondent, who is also a council member, pointed out. Respondents suggested that council members should hold permanent positions. 


\section{Discussion}

The study's objectives were to examine the role of self-regulation as a system of media accountability; and to ascertain the challenges encountered in using self-regulation as a system of media accountability.

In order to address the first objective, in-depth interviews were carried out on the structure, composition and functions of the Media Council of Kenya as the organ for self-regulation of the media in Kenya. Document reviews and direct observation was used to corroborate the evidence from the indepth interviews. The responses indicated that self-regulation played an indispensable role in ensuring standards in a free media environment. However, this was hampered by institutional weaknesses.

To address the second objective, interviewees were asked to comment on what they thought inhibited the Media Council of Kenya from realising its full potential in ensuring self-regulation of the media in Kenya. The responses revealed that self-regulation was beset by many challenges, including lack of funding, lack of awareness, competing interests, lack of teeth to enforce rules and an uncommitted media, among others.

An interesting, even ironic, observation is that even though there is agreement that self-regulation is the best way forward for media regulation in Kenya, respondents argued that the model should not be dominated by the media since the media were not committed enough to regulating themselves. The findings conform with McQuail's (2009) views, that the media generally do not like to be told what they ought to be doing and are not very sympathetic to those who question their actions.

On this score, Fengler (2003) criticises the self-regulation model as not sufficiently independent of the media themselves and for usually failing to exert enough pressure on powerful media. However, McQuail (2009) noted that the model is likely to eventually work because it is in the interest of media and media professionals and encourages self improvement and self-control. Bertrand (2005) suggests the composition of an ideal Press Council:

A true Press Council takes advantage of the fact that it brings together and represents the people who own the power to inform, those who possess the talent to inform and those who have the right to be informed. Also that it is a permanent institution that is democratic, independent, flexible, multifunctional, harmless and that its sole purpose is to improve media service to the public. And so it can afford to do more than just settle complaints (Bertrand, 2005). 
For comparison, Table 1 shows the composition of Press Councils in the Britain, Denmark, Flanders, Germany, Netherlands and Sweden, according to Daphne and Koene (2009) in their study of Press Councils in Western Europe. The media council also appears to have achieved very little in its existence and indeed, in two years, they had not resolved even a single case. It is possible to attribute this to teething problems, exacerbated by the limited funding to the council.

\begin{tabular}{|c|c|}
\hline Category & Key words \\
\hline Britain & $\begin{array}{l}17 \text { members, } 10 \text { of which are 'public members' } \\
\text { (including the chairman) and } 7 \text { chief-editors }\end{array}$ \\
\hline Denmark & $\begin{array}{l}\text { Chair (member of Supreme Court) and vice- } \\
\text { chair (lawyer), } 6 \text { members ( } 2 \text { journalists, } 2 \\
\text { editorial management, } 2 \text { 'public members') and } \\
6 \text { substitutes (with same distribution) }\end{array}$ \\
\hline Flanders & $\begin{array}{l}18 \text { effective members ( } 6 \text { from media companies, } \\
6 \text { from reporter associations and } 6 \text { 'public mem- } \\
\text { bers'), and } 18 \text { substitute members (identical } \\
\text { distribution) }\end{array}$ \\
\hline Germany & $\begin{array}{l}28 \text { members ( } 14 \text { from publishers, } 14 \text { from re- } \\
\text { porters' associations), no public members }\end{array}$ \\
\hline The Netherlands & $\begin{array}{l}\text { Chairman and } 3 \text { vice-chairmen (lawyers), mini- } \\
\text { mum } 10 \text { non-journalist members and minimum } \\
10 \text { journalist members (some nominated by the } \\
\text { Netherlands Union of Journalists, some by the } \\
\text { Netherlands Society of Chief-Editors) }\end{array}$ \\
\hline Sweden & $\begin{array}{l}\text { Chairman and } 3 \text { vice-chairmen (with jurisdic- } \\
\text { tion), } 14 \text { members ( } 4 \text { from publishers, } 2 \text { from } \\
\text { journalist association, } 2 \text { from press club, } 6 \\
\text { 'public members') and } 14 \text { substitutes (identical } \\
\text { distribution) }\end{array}$ \\
\hline Kenya & $\begin{array}{l}13 \text { members ( } 3 \text { from publishers, } 5 \text { from jour- } \\
\text { nalists associations, } 2 \text { from media training } \\
\text { institutions, } 1 \text { lawyer, } 1 \text { PR practitioner and } \\
1 \text { government official) }\end{array}$ \\
\hline
\end{tabular}

Bertrand (2005) suggests that press councils should be well financed to ensure independence and sources of funding could include media companies, government agencies, foundations, unions and private organisations. In the Kenyan case, funding has been limited to subscriptions by media houses and accreditation fees from journalists. 
The fact that the public are unaware of the existence of the council or what its role is probably the most significant challenge the council is facing. This is because the media's main role in society is to serve the public interest and press councils exist to listen to the public representations on errant media behaviour (McQuail, 2005). There is therefore an urgent need for a very vigorous public education on the Media Council and its role in society.

Having studied the operations of Press Councils in the North America, Pritchard (1991) emphasises the role of public awareness on the operations of Press Councils:

The second unresolved issue is the extent to which Press Councils succeed in establishing the boundaries of responsible media behaviour. Whatever the problems of the Quebec Press Council in indexing and compiling its jurisprudence, it is the only North American Press Council that has published a summary of ethical principles. The importance of deriving ethical principles and making them available to the public should not be minimised. Without such guidelines, media consumers and journalists are condemned to ad hoc-and, too often, post hoc-reasoning about responsible media behaviour. Press Councils in general have an educational role to which they should pay more attention. (Pritchard, 1991)

Overall, the performance of press councils has been the subject of debate all over the world as Bertrand (2005) found out:

A few years ago, I asked the councils themselves what their greatest achievement was. Their replies were dismal: no council felt it had clearly contributed to the improvement of media... Self-regulation or media accountability, whatever you call it, is undoubtedly slow. Its effects are rarely spectacular. (Bertrand, 2005)

\section{Conclusion}

From the findings, it is clear that media practitioners prefer self-regulation as the best tool for media accountability in Kenya. However, there is agreement that the Media Council of Kenya has performed below expectations, looking at its legal mandate as envisaged in the Media Act 2007. The council is invisible and ineffective; therefore, there is frustration with its work among the government, the public and the industry generally. 
Further, self-regulation of the media industry through the Media Council of Kenya is beset with many challenges which require immediate attention by both the government and the industry.

Press Councils around the world have been the subject of debate. The general trend has been to go the self-regulation way. But Bertrand (2005) contends that they lack teeth or authority.

Nevertheless, despite its imperfections, if the Media Council were to disappear, media consumers in Kenya would be the losers since a free media, unfettered by government regulation, is vital in securing the public interest against the excesses of the state. Although it is difficult to identify with certainty a broad influence of the council on the quality of journalism in Kenya, the council has provided the avenue for effective self-regulation of media in Kenya, which the industry has yet to exploit.

\section{Recommendations}

Emerging from the study, the following suggestions may be used to improve the operations of the Media Council of Kenya and press councils generally. They are outlined here.

- The objectives of the council should be whittled down so the council can focus on its core mandate to adjudicate disputes and enforce standards through the administration of the code of conduct. The Media Council should remain an ombudsman and leave professional functions to other media bodies such as training institutions and journalism associations.

- The council should be given more powers so that errant media do not get away with light reprimands, thereby eroding public trust and confidence in the concept of self-regulation. Similarly, the council should look for ways of speeding up the hearing process. Ideally, it should strive for a permanent Complaints Commission and the commissioners should not be tied elsewhere with other work.

- A very vigorous public education on the media and its role in society should be conducted. This will enable the public to understand what is permissible for the media to do and what it should not. There is need for a serious public education to ensure citizens know their rights and the mandate of the council. The council also needs to be much more proactive in making the public aware of its existence and 
functions and that anyone should know that the first port of call in case of a dispute is the council.

- The media must initiate a culture of editorial accountability to its sources of information, including the government, non-governmental institutions, and the public as consumers of news media. Journalists also need to be accountable to each other through internal mechanisms in their newsrooms. Some of the ways in which the media houses could achieve this is by having public editors.

- The council must create trust with the public as consumers of media. It should also act to protect consumers from harmful media products, such as pornography, hate speech and should set rules that bar those harmful products. Otherwise, there is need for citizens to organise themselves as consumers of media so that their voice is heard in a much more organised way.

- The performance of the council should be audited regularly, and the officials should sign performance contracts. However, to ensure operational independence, the complaints commissioners should be appointed directly, and not through the media council. In the same vein, the chairman of the council should not be a journalist or an operative of any media house to protect the council from conflict of interest or divided loyalty. The industry should therefore rethink the structure and composition of the council. For example, to ensure commitment to their work and remove the issue of divided loyalties, council members and commissioners should be made permanent for the duration of their terms.

- The industry must accept regulation and the attitude and commitment of the practitioners must change. For a start, media houses should boldly indicate in their publications that they are members of the council and advice people aggrieved by their work to seek redress at the council.

- The council should also be active in originating complaints and not waiting for complainants. In the words of one respondent, 'it should police, carry a big stick and walk around'.

- The Media Council needs to engage with other organisations carrying out media research in the country to avoid duplication of efforts. It should establish the terrain by a proper media survey in order to 
know how many journalists are practicing in the country or how many media houses are operating and put this in the public domain.

- There is also the need to establish the mechanisms required for the council to perform its mandate effectively by reviewing the law governing the council to incorporate the needed changes.

Bertrand's (2005) recommendations for a truly working Press Council should come in handy for the Kenyan media industry if self-regulation is to flourish as envisaged:

In my view, a PC's role is not just to satisfy a few individuals who have been hurt by the media, not just to avoid lawsuits, not just to discourage the state from limiting the freedom to make money. A PC is meant to improve the news media. Existing councils keep a very low profile. A true PC should not shy from seeking publicity, taking stands, establishing case law, taking initiatives when no complaint comes in. It should also assume all the missions found in the constitution of the original British PC, like reporting on the state and evolution of the media, like speaking out on threats to freedom. I believe a PC should also take an interest in the training of journalists, basic to an improvement of their services, and in research on how the news media actually function, what influence they have, what citizens need from them etc. Most importantly, a PC should be monitoring the press because what the press does worst is what it does not do. That is indispensable for taking initiatives on issues which the ordinary citizen most often cannot spot. (Bertrand, 2005, p. 12)

If all fails, it is upon the government to enforce the rule of law and order in the industry. One of the respondents, who works in the government warned:

The government will not sit and watch as the media behaves as it wishes. The government has a duty to the public, and will take action if the media fails to reform.

\section{Notes}

1. The New Partnership for Africa's Development (NEPAD) is a programme of the African Union (AU).

2. To address the challenge of funding, the Media Act 2007 has since been amended to allow for government funding. 


\section{References}

Abdi, J. and Deane, J. (2008). The Kenyan 2007 elections and their aftermath: The role of media and communication, Policy Briefing No.1, BBC World Service Trust, London

Article 19. (2005) Freedom and accountability: Safeguarding free expression through media self-regulation. London: Article 19.

Babbie, E. \& Mouton, J. (2001) The practice of social research. Oxford: Oxford University Press.

Bertrand, C-J. (2005). Media ethics and accountability. Pacific Journalism Review, 11(2), pp. 5-16.

BBC website (2003). Kenyan private media face curbs. Retrieved on 10 July 2010, from http://news.bbc.co.uk/2/hi/africa/3680377.stm

Christians, C. (1989). Self-regulation: a critical role for codes of ethics. In E. E. Gillmor \& T. L. Glasser (Eds.), Media freedom and accountability (pp. 35-54). New York: Greenwood Press.

Daphne C., Koene LL, M. (2009). Press councils in Western Europe, AMB.

Dawson, C. (2007). A practical guide to research methods. Oxford: HowToBooks.

Dennis, D. M., Deacon, D. et al. (1999). Researching communications. London: Arnold.

Desbarats, P. (1990). Guide to Canadian news media. Toronto: Harcourt Brace Jovanovich.

Fengler, S. (2003). Holding the news media and reporters accountable: A study of media reporters and media criticism in the US, Journalism and Mass Media Quarterly. 80(4), pp. 818-832.

Gillham, B. (2000). The research interview. London: Continuum.

Mason, J. (1996). Qualitative researching. London: Sage.

McQuail, D. (2009). McQuail's mass communication theory. London: Sage.

Media Council of Kenya. (2009). The state of the media report. Unpublished. Media Council of Kenya. (2009) Functions of the Media Council of Kenya. Retrieved on 6 July 2009, from www.mediacouncil.or.ke/About-Us/councilfunctions.html

Media Institute of East Africa (2009). To regulate or not? Retrieved on 8 July 2010, from www.eastafricapress.net

Oriare, P., Mshindi T. (2008). The media: Legal, regulatory and policy environment in Kenya. In Kenya media sector analysis report, Canadian International Development Agency.

Pritchard, D. (1991). The role of press councils in a system of media accountability: The case of Quebec. In Canadian Journal of Communication, Vol. 16. Retrieved on 5 April 2009, from www.cjc-online.ca/index.php/journal/article/view/583/489 Republic of Kenya (2007). Kenya Gazette Supplement, Acts 2007.

Rubin, H.J. \& Rubin, I.S. (2005). Qualitative interviewing: The art of hearing data. [2nd Ed.] Thousand Oaks, CA: Sage.

Tettey, W.J. (2002). The media, accountability and civic engagement in Africa. New York: UNDP 
Yin, R.K. (2009). Case study research design and methods. [3rd Ed.] Vol. 5. Thousand Oaks, CA: Sage.

Jared Obuya recently joined the Department of Communication Studies of Moi University, Kenya, to teach journalism and media studies. He has more than 10 years experience working as a journalist in Kenya and internationally, including with the $B B C$. His research interests are in media accountability. jaredobuya@hotmail.com

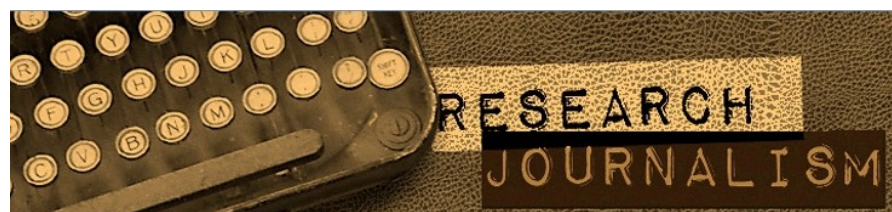

Journalism is not only a topic that can be studied.

It's a research methodology with a long and proud history.

Research Journalism is a new peer-reviewed journal that only publishes high quality journalism. It's articles are research into real events undertaken using journalism as a methodology.

Each piece has an accompanying commentary about the research process.

To discuss a submission, contact the editor on k.davies@ecu.edu.au

http://ro.ecu.edu.au/research_journalism/

http://researchjournalism.wordpress.com/

152 PACIFIC JOURNALISM REVIEW 18 (2) 2012 
Copyright of Pacific Journalism Review is the property of Auckland University of Technology and its content may not be copied or emailed to multiple sites or posted to a listserv without the copyright holder's express written permission. However, users may print, download, or email articles for individual use.

http://www.aut.ac.nz/depts/commstud/journ/pjrsubs.shtml 